\title{
Romanian Rural World Heritage Sites and Tourism Development
}

\author{
Cornelia Pop, Maria-Andrada Georgescu
}

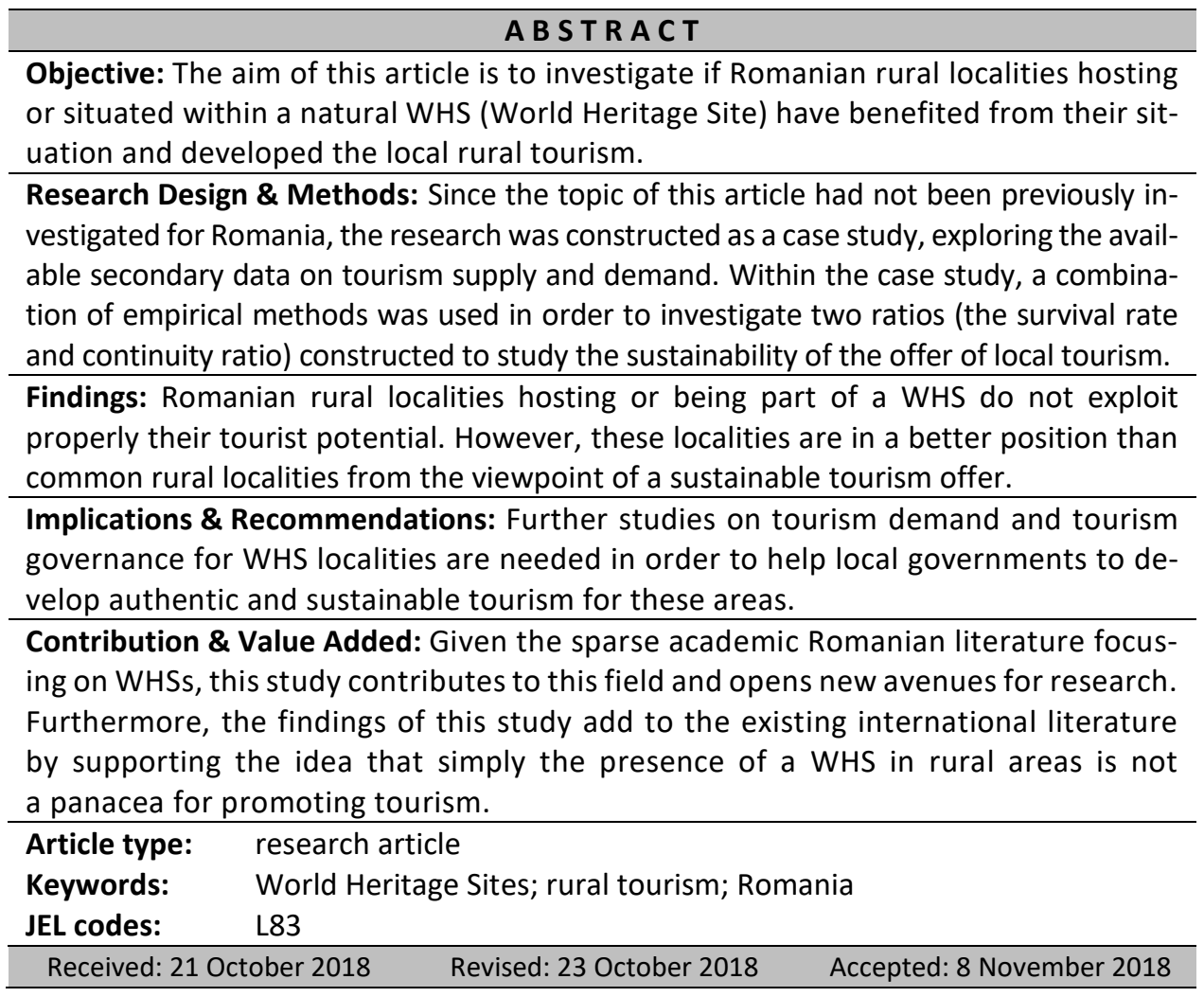

\section{Suggested citation:}

Pop, C., \& Georgescu, M.A. (2019). Romanian Rural World Heritage Sites and Tourism Development. Entrepreneurial Business and Economics Review, 7(1), 135-158. https://doi.org/10.15678/EBER.2019.070108 


\section{INTRODUCTION}

Heritage tourism has been considered an important and prosperous segment of the tourism industry since 1980s (Yang, Lin, \& Han, 2010; Jimura, 2011; Altunel \& Erkut, 2015; Santa-Cruz \& Lopez-Guzman, 2017). While this phenomenon is associated mostly with developed countries (Yang et al., 2010; Altunel \& Erkut, 2015), emerging economies are also aware of the importance of promoting their respective heritage (Yang \& Lin, 2014; Nicholas \& Thapa, 2010). A range of studies consider the WHS designation as a catalyst for increasing the (international) tourist inflow toward the respective destination by drawing the world's attention to its significance (Reyes, 2014; Li, Wu, \& Cai, 2008; Yang et al., 2010). WHS-related tourism can be viewed as a market niche of heritage tourism (Adie \& Hall, 2017; Nguyen \& Cheung, 2014) and WHS designations are more and more desired by the emerging economies for the expected increased tourist inflow and related tourism benefits (Nicholas \& Thapa, 2010). Consequently, the presence of WHSs in rural areas can enhance the development of rural tourism, accompanied by potential economic and social benefits (Iorio \& Corsale, 2010; Kastenholz \& Sparrer, 2009). This situation is particularly important to the emerging economies with prominent rural regions and significant rural population. Romania is one of these countries, with $46.4 \%$ rural population inhabiting about 12500 villages as of December 2016 (National Institute of Statistics via Tempoonline, 2018) and with a plethora of economic and social problems related to rural areas. Romanian rural tourism was identified as a major growth area by the Romanian Ministry of Tourism in 1995 (Hall, 2000). It is only natural to inquire if the presence of WHS within rural areas has enhanced the development of the local rural tourism.

The aim of this article is to investigate, through the case study methodology combined with empirical methods, if Romanian rural localities hosting a WHS or situated within the natural WHS, the Danube Delta, took advantage of this situation and developed the local rural tourism. For the present investigation the article combines information related to the accommodation offer, tourist activity, and the economic sustainability through the simple survival rate of economic entities owning accommodation units.

The remainder of the article is organised as follows: a presentation of literature review is followed by the data and methodology presentation, continued by the case study, followed by results, discussions and conclusions.

\section{LITERATURE REVIEW}

\section{WHS Tourism and Rural Areas}

The importance and the fast growth rate of heritage tourism since the $1980 \mathrm{~s}$ has been revealed by a series of academic studies (e.g. Yang et al., 2010; Altunel \& Erkut, 2015; Santa-Cruz \& Lopez-Guzman, 2017). Initially associated with developed countries (Yang et al., 2010; Altunel \& Erkut, 2015), the development of heritage tourism has been identified as beneficial for the emerging economies in terms of enhancing the national image and complementing the national identity and reputation (Li et al., 2008; Frey, Pamini, \& Steiner, 2013; Ung \& Vong, 2010), favouring economic development by attracting an increased number of tourists (Yang \& Lin, 2014; Nicholas \& Thapa, 2010). 
WHS tourism can be considered a niche market of heritage tourism (Adie \& Hall, 2017; Nguyen \& Cheung, 2014). The presence of a national heritage site on the World Heritage List (WHL) is often perceived as a brand or an icon (Boyd \& Timothy, 2006; Timothy, 2011), as a label (Yang et al., 2010) or as a 'magnet for visitors' (Fyall \& Rakic, 2006). Therefore, WHSs are often regarded as a panacea in promoting the host country tourism (Yang et al., 2010; Yang \& Lin, 2014) since a WHS designation increases the visibility of a destination and brings the world recognition of its special status (Chi, Cai, \& Li, 2017; Santa-Cruz \& Lopez-Guzman, 2017).

The body of studies investigating the WHS designation influence on tourist flow yielded controversial results. Several studies revealed positive effects of WHS-related tourism on a country's economic growth (Arezki, Piotrowski, \& Cherif, 2009), reported a positive relationship between WHS designation and the tourist number (Yang et al., 2010; Breakey, 2012; Su \& Lin, 2014) or showed a positive relation between tourists' willingness to revisit a country and WHS designation (Poria, Reichel, \& Cohen, 2011). Nevertheless, another group of studies raised questions regarding this enhancing tourist effect of WHS designation. These studies are mainly focused on a specific location, region or country and show there is either no significant or a limited effect on tourist inflow from Barcelona to Italian regions, from Israel to Macau and Japan (Poria et al., 2011; Cellini, 2011; Huang, Tsaur, \& Yang, 2012; Cuccia \& Rizzo, 2013; Cuccia, Guccio, \& Rizzo, 2016; Jones, Yang, \& Yamamoto, 2017). Furthermore, several works indicated that a WHS designation per se is not a panacea for attracting tourists (Poria et al., 2011) since the visitors are looking for a good WHS management and authentic experience (Richards, 2011; Poria et al., 2013), the quality of cultural heritage counting more than quantity (Cuccia et al., 2016).

Despite the controversial results regarding the relationship between WHS designation and tourist inflow, the emerging countries are increasingly seeking to acquire the WHS brand (Nicholas \& Thapa, 2010) due to the enhanced international visibility of the respective WHSs (Jimura, 2011; Chi et al., 2017; Santa-Cruz \& Lopez-Guzman, 2017) and the potential for regional or local WHSs to act as a factor for tourism and, consequently, economic development (Richards, 2011; Jaafar et al., 2015). Furthermore, emerging economies have important rural regions where rural tourism can be considered as one of the tools that can assist in developing these territories by improving the economic and social conditions (Iorio \& Corsale, 2010; Kastenholz \& Sparrer, 2009; Cunha, Kastenholz, \& Carneiro, 2018). At the rural level, more than in urban areas, WHS presence can act as an enhanced catalyst for the development of rural tourism and can become a powerful factor for the revitalisation of traditional local/regional industries through an increased awareness and promotion of local products, the preservation of local/regional heritage and cultural identity, job creation and new investments (Jimura, 2011; Jaafar et al., 2015; Cunha et al., 2018). Notwithstanding the identified benefits, the academic research shows that the relationship between WHS designation and tourism development is usually characterised by tensions (Su \& Wall, 2014). Therefore, mainly in rural areas, the participation of local residents in WHS management, conservation and tourism development is essential for the sustainable development of respective rural localities as tourist destinations (Nicholas \& Thapa, 2010; Rasoolimanesh, Jaafar, Ahmad, \& Bairghi, 2017). Further research revealed that community participation in (WHS) tourism development is related to residents' perception on how this process 
impacts their quality of life at individual and community levels (Latkova \& Vogt, 2012; Jaafar et al., 2015). Nonetheless, the overpriotirisation of tourism in WHS locations, based on central and local authorities tendency to focus on economic gain (Su \& Wall, 2014; Poria et al., 2011), can negatively affect or, in extremis, destroy the environmental and cultural integrity of the respective WHSs (Li et al., 2008; Yang et al., 2010; Jimura, 2011; Caust \& Vecco, 2017). This situation is further enhanced by emerging countries' insufficient management skills and resources for effective site management of their WHSs (Caust \& Vecco, 2017; Landorf, 2009).

\section{Romanian Rural Tourism and WHSs}

Romania, as an emerging economy since the 1990s, had to face the complex problems of the domestic rural areas still influenced by the poor decisions of the communist period. The series of studies by Turnock $(1991,1996,1999)$ and Bordanc and Turnock (1997) discuss the early post-communist initiatives and projects for the Romanian rural tourism, with rural tourism identified as a major growth area by the Romanian Ministry of Tourism in 1995 (Hall, 2000). Although the modest rural tourism development took place 'rather despite of government actions' (Hall, 2004), many programmes and initiatives being abandoned mainly due to political instability and constant lack of financial resources.

Despite entering the WHL with the Danube Delta in 1991 and followed by three other WHSs in 1993 (details in Table 2), there was almost no focus in the academic literature on the Romanian rural WHSs and their role in tourism development. Only recently the series of studies by lorio and Corsale $(2010,2014)$ and Corsale and lorio (2014) focused mainly on the case of Viscri, a village hosting a WHS. The domestic academic literature on rural WHSs is also sparse, to the best of our knowledge only three studies chose to focus on this topic: Pop and Coros (2016) considering the accommodation offering of rural localities hosting WHS, Pop and Coros (2018) focusing on the effects of the Danube Delta WHS status on the region's rural tourism, and latu, Ibanescu, Stoleriu and Munteanu (2018) presenting the influence of rural WHSs on the growth of rural tourism. This article adds a new perspective on Romanian WHSs and rural tourism and complements the existing findings.

\section{DATA AND METHODOLOGY}

The data used in this study are from secondary sources: the official databases provided by the Romanian Authority for Tourism and the data supplied by the Romanian National Institute for Statistics (NIS) via Tempo-online database. The data were extracted for the years 2005 and 2016 at the level of every commune (the smallest administrative unit in Romania, found only in rural areas) that hosts at least one WHS or is situated within the natural WHS Danube Delta. Further, the data were grouped by rural WHS types based on the data at the commune level (available upon request).

This study does not include the communes related to the Romanian primeval beech forests since they were designated (for Romania) only in 2017.

The article also uses the simple survival rate (SSR) for lodgings and the continuity rate (CR) for the economic entities owning the lodgings as proposed by Pop and Coros (2018). These two measures are adapted to the data available in Romania. While the perspective offered by SSR and CR would have been complete if accompanied by the respective economic entities' financial performance, this is not possible for this study 
given the dominance of individual enterprises for which no such information is publicly available via the Romanian Ministry of Finance.

The general methodology used was that of a case study, combining deductive and inductive approaches, and mixing a combination of empirical methods (OLS regression, principal component analysis (PCA) and index decomposition analysis (IDA) to confirm the regression results, given the small number of observations) for a better understanding of factors that influence the SSR and CR.

Appendix B presents the descriptive statistics. The correlation coefficients, their significance, and the variance inflation factors for the variables were taken into consideration. No multicollinearity was detected among any variables. The information is available upon request.

For IDA, this study uses the logarithmic mean divisia index (LMDI) as proposed by Balezentis, Krisciukaitiene, Balezentis and Garland (2012) based on the report of Ang (2005).

\section{ROMANIAN RURAL WORLD HERITAGE SITES, THE LODGING SURVIVAL RATE AND THE OWNER CONTINUITY RATE}

\section{Romanian WHS: A General Presentation}

Romania, with eight WHSs, of which six are cultural, is above the average number of WHS of 5.50, respectively 4.23 for cultural WHS, reported by Su and Lin (2014) for 66 countries between 2000 and 2009. Therefore, it is expected for Romania to have similar results as the neighbouring countries, Bulgaria and Hungary, with a comparable number of WHSs. However, the data in Table 1 show that Romania has the lowest rank regarding tourism competitiveness, the lowest international tourist receipts and the lowest tourism direct contribution to the Gross Domestic Product (GDP).

\section{Romanian Rural WHSs: Accommodation Facilities, Tourist Activities and Tourist Potential}

Table 2 presents the main characteristics of WHSs in Romania. The visualisation of their geographical distribution is presented in Appendix A. The WHSs are grouped in several clusters within the counties of Maramures (the wooden churches), Suceava (the churches of Moldavia), Hunedoara and Alba (the Dacian fortresses) and Tulcea (the Danube Delta). Moreover, the majority of these WHSs are located in rural areas.

The pre-accession development plans for Romanian (rural) tourism development are difficult to almost impossible to identify. Post-accession to the European Union (EU), two central documents include the rural tourism: the 2007-2016 Master Plan for National Tourism Development and the National Rural Development Program (NRDP) for 2007-2013 and 2014-2020. Although considered a priority, rural tourism is granted only a small space in the Master Plan. The mention of WHSs is sparse and briefly discusses the need for restoration of these monuments and the need to manage the expected large number of tourists within the localities hosting WHSs. The NRDP gives more attention to rural tourism since it provides most of the financing sources for its development. Nonetheless, the reference to WHSs is similar to the Master Plan. Neither of these central documents provides an integrated development strategy for the rural communes (or the component villages) where WHSs are located, nor consider the necessity to grant a special status to these localities in order to support sustainable and authentic rural tourism development based on their cultural and natural characteristics. 
Table 1. Selected Data Concerning Romania's Position as a Tourism Destination

\begin{tabular}{|c|c|c|c|c|c|c|c|}
\hline \multirow{2}{*}{$\begin{array}{c}\text { Country, WHSs number } \\
\text { and type }\end{array}$} & \multicolumn{7}{|c|}{ World Economic Forum: Travel and Tourism Competitiveness Index rank } \\
\hline & 2007 & 2008 & 2009 & 2011 & 2013 & 2015 & 2017 \\
\hline $\begin{array}{l}\text { Bulgaria; } 10 \text { WHSs } \\
\text { (3 natural*); } 7 \text { cultural) }\end{array}$ & 54 & 43 & 50 & 48 & 50 & 49 & 45 \\
\hline $\begin{array}{l}\text { Hungary; } 8 \text { WHSs } \\
\text { (1 natural; } 6 \text { cultural) }\end{array}$ & 40 & 33 & 38 & 38 & 39 & 41 & 49 \\
\hline $\begin{array}{l}\text { Romania; } 8 \text { WHSs } \\
\text { ( } 2 \text { natural*); } 6 \text { cultural) }\end{array}$ & 76 & 69 & 66 & 63 & 68 & 66 & 68 \\
\hline \multirow{2}{*}{ Country } & \multicolumn{7}{|c|}{ International tourist arrivals at frontiers (thousands persons) } \\
\hline & 2007 & 2008 & 2009 & 2011 & 2013 & 2015 & 2017 \\
\hline Bulgaria & 5151 & 5780 & 5739 & 6328 & 6897 & 7099 & $\mathrm{n} / \mathrm{a}$ \\
\hline Hungary & 8638 & 8814 & 9058 & 10250 & 10675 & 14316 & $\mathrm{n} / \mathrm{a}$ \\
\hline Romania & 7772 & 8862 & 7575 & 7611 & 8019 & 9331 & $\mathrm{n} / \mathrm{a}$ \\
\hline \multirow{2}{*}{ Country } & \multicolumn{7}{|c|}{ International tourist receipts (USD millions) } \\
\hline & 2007 & 2008 & 2009 & 2011 & 2013 & 2015 & 2017 \\
\hline Bulgaria & 3350 & 4204 & 3728 & 3967 & 4059 & 3146 & $\mathrm{n} / \mathrm{a}$ \\
\hline Hungary & 4721 & 5935 & 5631 & 5580 & 5366 & 5326 & $\mathrm{n} / \mathrm{a}$ \\
\hline Romania & 1610 & 1990 & 1234 & 1418 & 1590 & 1711 & $\mathrm{n} / \mathrm{a}$ \\
\hline \multirow{2}{*}{ Country } & \multicolumn{7}{|c|}{ Tourism direct contribution to GDP (\%) } \\
\hline & 2007 & 2008 & 2009 & 2011 & 2013 & 2015 & $2017^{* *)}$ \\
\hline Bulgaria & 3.57 & 3.35 & 3.15 & 2.90 & 3.07 & 2.77 & 3.06 \\
\hline Hungary & 1.95 & 2.09 & 2.16 & 2.23 & 2.04 & 2.35 & 2.42 \\
\hline Romania & 1.45 & 1.42 & 1.30 & 1.27 & 1.28 & 1.38 & 1.44 \\
\hline
\end{tabular}

${ }^{*}$ ) The primeval beech forest natural site spread across Europe, being also designated in Bulgaria and Romania in 2017, adding one new natural WHS within each country to the previously existing natural WHSs.

$\left.{ }^{* *}\right)$ estimated by WTTC Data Gateway https://tool.wttc.org/

Source: World Economic Forum Reports (2007, 2008, 2009, 2011, 2013, 2015, 2017) and https://www.worldheritagesite.org/list; UNWTO Tourism Highlights 2008, 2009, 2011, 2013, 2015, 2017 and World Bank Open Data: https://data.worldbank.org, WTTC Data Gateway https://tool.wttc.org/

Table 3 and 4 show the modest position of WHSs accommodation offer (between 7\% and $8 \%$ of rural lodgings and around $6.5 \%$ of rooms in rural areas), and the low number of incoming tourists (about $3.5 \%$ of total tourist arrivals).

Despite the modest position of WHS localities within the rural accommodation offer and tourist arrivals, the growth rates of lodgings and rooms in these localities, of $97.17 \%$ and respectively $125.63 \%$, are higher than the lodging and room growth rates at the national rural level, of $75.28 \%$ and respectively $115.58 \%$, based on the data in Table 3 . The Dacian fortress localities registered the highest lodging and room growth rates of $433.33 \%$ and respectively $835.71 \%$. The wooden churches localities are the only group which registered a decrease in the number of lodgings (-10.42\%). All WHS localities recorded a growth of rooms. Also Table 3 shows a higher concentration of lodgings in the Danube Delta localities, followed by the churches of Moldavia localities.

While in 2005 the Danube Delta localities registered the highest number of tourists, by 2016 the churches of Moldavia localities became the most visited destinations. The cultural WHS localities registered a growth of $283.43 \%$ in tourist arrivals, compared to the 
growth of tourists for 'other destinations' of $168.52 \%$, with the highest growth rate of $2536.07 \%$ for the fortified church localities (based on Table 4). The Danube Delta localities recorded the lowest growth rate of tourist arrivals (10.93\%), however, well above the rate reported for the whole Danube Delta, including urban areas, of only $0.72 \%$.

Table 2. Selected Characteristics of Rural WHSs

\begin{tabular}{|c|c|c|c|c|c|c|c|c|}
\hline Description & $\begin{array}{l}\text { Danube } \\
\text { Delta }\end{array}$ & $\begin{array}{c}\text { Dacian } \\
\text { For- } \\
\text { tresses }\end{array}$ & $\begin{array}{l}\text { Fortified } \\
\text { churches }\end{array}$ & $\begin{array}{c}\text { Churches } \\
\text { of Mol- } \\
\text { davia }\end{array}$ & $\begin{array}{l}\text { Wooden } \\
\text { churches }\end{array}$ & $\begin{array}{l}\text { Sighisoara } \\
\text { citadel and } \\
\text { city center }\end{array}$ & $\begin{array}{c}\text { Horezu } \\
\text { Mon- } \\
\text { astery }\end{array}$ & $\begin{array}{c}\text { Primeval } \\
\text { beech } \\
\text { forests }\end{array}$ \\
\hline $\begin{array}{l}\text { WHS desig- } \\
\text { nation }\end{array}$ & 1991 & 1999 & 1993 & 1993 & 1999 & 1999 & 1993 & 2017 \\
\hline $\begin{array}{l}\text { No. of loca- } \\
\text { tions, county, } \\
\text { map position } \\
\text { in Appendix A }\end{array}$ & $\begin{array}{c}1 \\
\text { Tulcea } \\
\text { (32) }\end{array}$ & $\begin{array}{c}6 \\
\text { Alba; } \\
\text { Hunedo } \\
\text { ara } \\
\text { (1 to 6) }\end{array}$ & $\begin{array}{c}7 \\
\text { Alba; Brasov; } \\
\text { Harghita; } \\
\text { Mures; Sibiu } \\
\text { (9 to 15) }\end{array}$ & $\begin{array}{c}8 \\
\text { Suceava } \\
\text { (24 to 31) }\end{array}$ & $\begin{array}{c}8 \\
\text { Maramures } \\
\text { (16 to 23) }\end{array}$ & $\begin{array}{c}1 \\
\text { Mures } \\
(8)\end{array}$ & $\begin{array}{c}1 \\
\text { Valcea } \\
(7)\end{array}$ & $\begin{array}{c}12 \\
n / a \\
(33 \text { to } 44)\end{array}$ \\
\hline $\begin{array}{l}\text { Of which in } \\
\text { rural areas }\end{array}$ & 1 & 6 & 7 & $\begin{array}{c}5 \\
\text { (25 to } 29)\end{array}$ & $\begin{array}{c}7 \\
(16,18 \text { to } 23) \\
\end{array}$ & 0 & 0 & $\begin{array}{c}\text { Not investi- } \\
\text { gated }\end{array}$ \\
\hline $\begin{array}{l}\text { No. of com- } \\
\text { munes cover- } \\
\text { ing the WHS } \\
\text { locations }\end{array}$ & 10 & 4 & 7 & 5 & 6 & 0 & 0 & $\begin{array}{l}\text { Not investi- } \\
\text { gated }\end{array}$ \\
\hline $\begin{array}{l}\text { Communes' } \\
\text { websites and } \\
\text { languages }\end{array}$ & $\begin{array}{c}10 \text { communes with } \\
\text { websites; } \\
2 \text { only } \\
\text { in Romanian. }\end{array}$ & $\begin{array}{l}4 \text { com- } \\
\text { munes } \\
\text { with } \\
\text { web- } \\
\text { sites, } \\
\text { only in } \\
\text { Roma- } \\
\text { nian }\end{array}$ & $\begin{array}{c}1 \text { commune } \\
\text { with noweb- } \\
\text { site; } 2 \text { com- } \\
\text { munes offer } \\
\text { Google Trans- } \\
\text { latealterna- } \\
\text { tive }\end{array}$ & $\begin{array}{c}5 \text { com- } \\
\text { munes } \\
\text { with web- } \\
\text { sites, only } \\
\text { in Roma- } \\
\text { nian }\end{array}$ & $\begin{array}{l}2 \text { communes } \\
\text { with noweb- } \\
\text { sites; } 1 \text { com- } \\
\text { mune offers } \\
\text { Google Trans- } \\
\text { late alterna- } \\
\text { tive }\end{array}$ & $\mathrm{n} / \mathrm{a}$ & $\mathrm{n} / \mathrm{a}$ & $\begin{array}{l}\text { Not investi- } \\
\text { gated }\end{array}$ \\
\hline $\begin{array}{l}\text { WHSs men- } \\
\text { tioning on } \\
\text { websites }\end{array}$ & $\begin{array}{c}\text { No direct mention } \\
\text { of the WHSs }\end{array}$ & $\begin{array}{l}\text { No } \\
\text { men- } \\
\text { tion of } \\
\text { the } \\
\text { WHSs }\end{array}$ & $\begin{array}{l}5 \text { communes } \\
\text { mention the } \\
\text { respective } \\
\text { WHS on their } \\
\text { website/ } \\
\text { dedicated } \\
\text { page }\end{array}$ & $\begin{array}{l}2 \text { com- } \\
\text { munes } \\
\text { mention } \\
\text { their re- } \\
\text { spective } \\
\text { WHSs }\end{array}$ & $\begin{array}{l}6 \text { communes } \\
\text { mention the } \\
\text { respective } \\
\text { WHS on their } \\
\text { website/ } \\
\text { dedicated } \\
\text { page }\end{array}$ & $\begin{array}{l}\text { Not investi- } \\
\text { gated }\end{array}$ & $\begin{array}{l}\text { Not in- } \\
\text { vesti- } \\
\text { gated }\end{array}$ & $\begin{array}{l}\text { Not investi- } \\
\text { gated }\end{array}$ \\
\hline $\begin{array}{l}\text { Tourism strat- } \\
\text { egy on web- } \\
\text { sites }\end{array}$ & $\begin{array}{c}8 \text { communes } \\
\text { icluded tourism in } \\
\text { their overall strat- } \\
\text { egy, of which } 2 \\
\text { communes with } \\
\text { better sections } \\
\text { dedicated to tour- } \\
\text { ism }\end{array}$ & \begin{tabular}{|l} 
No strat- \\
egy for \\
tourism \\
available
\end{tabular} & $\begin{array}{l}2 \text { communes } \\
\text { included tour- } \\
\text { ism in their } \\
\text { overall strat- } \\
\text { egy }\end{array}$ & $\begin{array}{c}\text { No strategy } \\
\text { for tourism } \\
\text { available }\end{array}$ & $\begin{array}{l}\text { No strategy } \\
\text { for tourism } \\
\text { available }\end{array}$ & $\begin{array}{l}\text { Not investi- } \\
\text { gated }\end{array}$ & $\begin{array}{l}\text { Not in- } \\
\text { vesti- } \\
\text { gated }\end{array}$ & $\begin{array}{c}\text { Not investi- } \\
\text { gated }\end{array}$ \\
\hline
\end{tabular}

Source: https://www.worldheritagesite.org/list; authors' compilations based on the communes' websites.

The occupancy rates remain low despite the increase in tourist arrivals. Only the Danube Delta localities register occupancy rates above $25 \%$. This situation suggests the existence of informal accommodation units, mentioned by Radan-Gorska (2013) and the 2007-2026 Master Plan, and/or incomplete reporting of tourist arrivals and their overnight stays by the registered 
lodgings. Furthermore, the length of stay decreased for all four cultural WHS localities indicating a scarcity of alternative entertainment facilities. The Danube Delta localities are the only group which recorded a one day increase in the length of stay between 2005 and 2016.

Table 3. Accommodation Capacity and their Owners in WHS Localities

\begin{tabular}{|c|c|c|c|c|c|c|}
\hline \multirow{2}{*}{ Rural WHSs by types } & \multicolumn{2}{|c|}{ No. of lodgings } & \multicolumn{2}{|c|}{ No. of rooms } & \multicolumn{2}{|c|}{ No. of lodging owners } \\
\hline & 2005 & 2016 & 2005 & 2016 & 2005 & 2016 \\
\hline The Danube Delta & 74 & 226 & 944 & 2.264 & 58 & 166 \\
\hline The Dacian fortresses & 3 & 16 & 14 & 131 & 3 & 13 \\
\hline The fortified churches & 22 & 33 & 51 & 164 & 22 & 30 \\
\hline The churches of Moldavia & 65 & 100 & 377 & 742 & 62 & 87 \\
\hline The wooden churches & 48 & 43 & 194 & 264 & 45 & 38 \\
\hline Total rural WHSs & 212 & 418 & 1580 & 3565 & 190 & 334 \\
\hline Total rural (national) & 3054 & 5353 & 25427 & 54816 & $\mathrm{n} / \mathrm{a}$ & $\mathrm{n} / \mathrm{a}$ \\
\hline
\end{tabular}

Source: The Authority for Tourism databases and Pop et al. (2017).

Table 4. Tourist Activities in WHS Localities

\begin{tabular}{|c|c|c|c|c|c|c|c|c|}
\hline \multirow[t]{2}{*}{ Rural WHSs by types } & \multicolumn{2}{|c|}{$\begin{array}{l}\text { Tourist arrivals } \\
\text { (persons) }\end{array}$} & \multicolumn{2}{|c|}{$\begin{array}{l}\text { Estimated foreign } \\
\text { tourist arrivals*) } \\
\text { (persons) }\end{array}$} & \multicolumn{2}{|c|}{$\begin{array}{c}\text { Occupancy rate } \\
\text { (\%) }\end{array}$} & \multicolumn{2}{|c|}{$\begin{array}{l}\text { Length of } \\
\text { stay (days) }\end{array}$} \\
\hline & 2005 & 2016 & 2005 & 2016 & 2005 & 2016 & 2005 & 2016 \\
\hline The Danube Delta & 16155 & 17922 & 4825 & 4174 & 29.61 & 39.00 & 1.7 & 2.7 \\
\hline The Dacian fortresses & 606 & 1279 & 116 & 193 & 14.75 & 11.89 & 3.4 & 1.8 \\
\hline The fortified churches & 244 & 6432 & 47 & 970 & 2.28 & 17.26 & 2.0 & 1.6 \\
\hline The churches of Moldavia & 8490 & 26338 & 1630 & 3972 & 11.59 & 19.41 & 1.9 & 1.8 \\
\hline The wooden churches & 1492 & 7484 & 287 & 1129 & 6.17 & 10.60 & 2.3 & 1.7 \\
\hline Total rural WHSs & 26987 & 59455 & 6905 & 10438 & 15.30 & 21.33 & 1.8 & 2.0 \\
\hline Total for the Danube Delta**) & 72592 & 73114 & 16566 & 17367 & 28.40 & 24.70 & 2.0 & 2.0 \\
\hline $\begin{array}{l}\text { Total for other destina- } \\
\text { tions***) }\end{array}$ & 666650 & 1790082 & 129305 & 269750 & 20.50 & 19.10 & 2.2 & 2.0 \\
\hline
\end{tabular}

*) NIS does not report the foreign tourists at the commune level. This estimation is based on the data provided by NIS for the Danube Delta and for 'other destinations'. For more details see the two notes below.

${ }^{* *}$ ) The data for the Danube Delta reported by the NIS includes Tulcea, the county residence, and the town of Sulina

$* * *)$ 'other destinations' include urban and the rural destinations not included under spa resorts, mountain resorts, littoral resorts, county residences and the Danube Delta.

Source: NIS via Tempo-online database and NIS Romanian Tourism in Figures $(2005,2016)$.

Table 5 combines the information regarding the population and the tourist potential of WHS localities as assessed by NPRD.

Compared with the decline in the rural population at the national level between 2005 and 2016, the population decline for WHS localities is insignificant. Moreover, for three of the cultural WHS localities groups, the overall population increased. The dominant workforce group, the population between 30 and 64 years, grew similar to the evolution at the national level. The unemployment rate decreased in all cases between 2010 and 2016, though only the Danube Delta localities and wooden churches localities have unemployment rates lower than the country average.

According to NPRD, the tourism potential of cultural WHS localities is very high, while for the Danube Delta localities is high. This assessment is not detailed by NPRD. 
Table 5. Population, Unemployment Rate and Tourism Potential of WHS Localities

\begin{tabular}{|l|r|r|r|r|r|r|r|}
\hline \multirow{2}{*}{ Rural WHSs by types } & \multicolumn{2}{|c|}{$\begin{array}{c}\text { Population } \\
\text { (persons) }\end{array}$} & \multicolumn{2}{|c|}{$\begin{array}{c}\text { Population be- } \\
\text { tween 30 and 64 } \\
\text { years (persons) }\end{array}$} & \multicolumn{2}{|c|}{$\begin{array}{l}\text { Unemployment } \\
\text { rate (\%) }\end{array}$} & $\begin{array}{r}\text { Average score of tour- } \\
\text { ism potential (score and } \\
\text { description) }\end{array}$ \\
\cline { 2 - 9 } & $\mathbf{2 0 0 5}$ & $\mathbf{2 0 1 6}$ & \multicolumn{1}{|c|}{$\mathbf{2 0 0 5}$} & $\mathbf{2 0 1 6}$ & $\mathbf{2 0 1 0}$ & $\mathbf{2 0 1 6}$ & $\mathbf{2 0 1 2}$ \\
\hline The Danube Delta & 20964 & 19300 & 8196 & 8913 & 4.97 & 3.80 & $\begin{array}{r}26.66 \\
\text { (high) }\end{array}$ \\
\hline The Dacian fortresses & 11694 & 11734 & 5012 & 5437 & 9.45 & 6.55 & $\begin{array}{r}47.89 \\
\text { very high }\end{array}$ \\
\hline The fortified churches & 21639 & 22970 & 10248 & 12079 & 9.57 & 8.07 & $\begin{array}{r}46.23 \\
\text { very high }\end{array}$ \\
\hline The churches of Moldavia & 28174 & 29705 & 10956 & 13027 & 6.83 & 6.47 & $\begin{array}{r}39.37 \\
\text { very high }\end{array}$ \\
\hline The wooden churches & 22089 & 20787 & 9553 & 9896 & 2.75 & 1.98 & $\begin{array}{r}43.18 \\
\text { very high }\end{array}$ \\
\hline Total rural WHSs & $\mathbf{1 0 4 5 4 3}$ & $\mathbf{1 0 4 4 9 6}$ & $\mathbf{4 3 9 6 5}$ & $\mathbf{4 9 3 5 2}$ & $\mathbf{6 . 4 2}$ & $\mathbf{5 . 1 9}$ & $\begin{array}{r}\mathbf{3 9 . 0 8} \\
\text { very high }\end{array}$ \\
\hline Rural (national level) & 9476912 & 9113095 & 4025729 & 4140497 & $\left.5.90^{*}\right)$ & $4.80^{* 1}$ & $\mathrm{n} / \mathrm{a}$ \\
\hline
\end{tabular}

Source: NIS via Tempo-online database and NPRD https://portal.afir.info/informatii_generale_pndr_pndr_2007 _2013_masura_313_incurajarea_activitatilor_turistice

\section{Simple Survival Rate (SSR) and Continuity Rate (CR) in Rural WHS Localities}

SSR and CR offer a perspective regarding the economic sustainability of accommodation facilities and the related economic entities which, in Romania's case, are also the owners of the operated lodgings. The attempt to understand the economic sustainability of tourist lodgings is an important part of the overall process of sustainable tourism development.

Table 6 presents the number of communes included in the calculation of SSR and $C R$ and the reasons why 11 communes were excluded. The SSR and CR used in this case study are adapted to the data available in Romania.

Table 7 presents the SSR by types of WHS localities, showing higher rates for the churches of Moldavia, under the influence of religious tourism, and the Danube Delta, confirming the higher attractiveness of natural WHSs as highlighted by Su and Lin (2014), supported also by the data regarding the tourist arrivals per 100 inhabitants. The lowest SSR is registered by the fortified church localities.

This is the second attempt to calculate the CR. The first was made by Pop and Coros (2018) only for WHS Danube Delta. The CR of the economic entities owning lodging facilities is lower that the SSR. This points toward the selling or transferring the lodgings to other economic entities ${ }^{1}$. The highest CR is, similar to SSR, within the churches of Moldavia localities, while the lowest is registered by the fortified churches localities.

\footnotetext{
${ }^{1}$ The CR might be higher if the transfer toward a new economic entity formed by a family member would be taken into consideration. However, there is no information available regarding the persons involved in individual enterprises and not always a similarity in the family name means there are involved members of the same family. Therefore, these similarities were ignored for the present study.
} 
Table 6. The Number of Communes Included in the Study and the Reasons for the Exclusion

\begin{tabular}{|c|c|c|c|}
\hline Rural WHSs by types & $\begin{array}{c}\text { Number of } \\
\text { communes } \\
\text { in or hosting } \\
\text { WHSs }\end{array}$ & $\begin{array}{c}\text { Number of } \\
\text { communes } \\
\text { included in } \\
\text { the study }\end{array}$ & Comments \\
\hline The Danube Delta & 10 & 7 & $\begin{array}{l}\text { For } 3 \text { communes SSR and CR could not be calculated due to the } \\
\text { absence of lodgings in } 2005\end{array}$ \\
\hline The Dacian fortresses & 4 & 2 & $\begin{array}{l}\text { For } 2 \text { communes SSR and CR could not be calculated due to the } \\
\text { absence of lodgings in } 2005\end{array}$ \\
\hline The fortified churches & 7 & 3 & $\begin{array}{l}\text { Two communes (Calnic, Alba county and Valea Viilor, Si- } \\
\text { biu county) reported no lodgings for } 2005 \text { and 2016; } \\
\text { For other } 2 \text { communes the SSR and CR could not be cal- } \\
\text { culated due to the absence of lodgings in } 2005\end{array}$ \\
\hline $\begin{array}{l}\text { The churches } \\
\text { of Moldavia }\end{array}$ & 5 & 4 & $\begin{array}{l}\text { These } 4 \text { communes include Moldovita locality which is in the } \\
\text { proximity of Moldovita Monastery. This inclusion was de- } \\
\text { cided based on the study of Pop and Coros (2016); One com- } \\
\text { mune (Arbore, Suceava county) reported no lodgings for } \\
2005 \text { and 2016; For one commune SSR and CR could not be } \\
\text { calculated due to the absence of lodgings in } 2005 \text {. }\end{array}$ \\
\hline The wooden churches & 6 & 6 & - \\
\hline Total rural WHSs & 32 & 22 & - \\
\hline
\end{tabular}

Source: authors' compilation.

The case of fortified churches needs further investigations in order to understand the low rates. Though, the data in Table 4 already indicate a poor start in 2005 (with an occupancy rate of $2.28 \%$ ) and a decrease in the length of stay by 0.4 days that might be related to the lack of alternative entertainment facilities that can influence the tourist stay.

Table 7. Simple Survival Rate, Continuity Rate, Ownership Ratio and Carrying Capacity for WHS Localities

\begin{tabular}{|c|c|c|c|c|c|c|c|c|}
\hline \multirow{3}{*}{ Rural WHSs by types } & \multirow{3}{*}{$\begin{array}{c}\text { SSR (\%) (sim- } \\
\text { ple survival } \\
\text { rate) }\end{array}$} & \multirow{3}{*}{$\begin{array}{c}\text { CR }(\%) \\
\text { (continu- } \\
\text { ity rate) }\end{array}$} & \multirow{2}{*}{\multicolumn{2}{|c|}{$\begin{array}{c}\text { Ownership } \\
\text { ratio }\end{array}$}} & \multicolumn{4}{|c|}{ Carrying capacity*) } \\
\hline & & & & & \multicolumn{2}{|c|}{$\begin{array}{c}\text { Bed places per } 100 \\
\text { inhabitants }\end{array}$} & \multicolumn{2}{|c|}{$\begin{array}{c}\text { Tourist arrivals per } \\
100 \text { inhabitants }\end{array}$} \\
\hline & & & 2005 & 2016 & 2005 & 2016 & 2005 & 2016 \\
\hline The Danube Delta & 41.89 & 32.76 & 1.28 & 1.36 & 9 & 25 & 77 & 93 \\
\hline The Dacian fortresses & 33.33 & 33.33 & 1.00 & 1.23 & 4 & 7 & 5 & 11 \\
\hline The fortified churches & 27.27 & 18.18 & 1.00 & 1.10 & 0 & 2 & 1 & 28 \\
\hline The churches of Moldavia & 46.15 & 33.87 & 1.05 & 1.15 & 5 & 5 & 30 & 89 \\
\hline The wooden churches & 29.17 & 20.83 & 1.07 & 1.13 & 0 & 3 & 7 & 36 \\
\hline Total rural WHSs & 38.68 & 25.94 & 1.12 & 1.25 & 4 & 7 & 26 & 57 \\
\hline
\end{tabular}

$\left.{ }^{*}\right)$ calculated as suggested by Defining, measuring and evaluating carrying capacity in European tourism destinations, B4-3040/2000/294577/MAR/D2, http://ec.europa.eu/environment/iczm/pdf/tcca_en.pdf Source: authors' calculations.

Table 8 presents the data regarding the structure of survivor lodgings and their respective owners. The results are similar to those reported by Pop and Balint (2017) for the rural localities with at least ten lodgings. However, by including all WHS localities in the 
study, the stronger presence of rural pensions and individual enterprises in the localities with less than ten lodgings became evident.

Table 8. The Structure and Profile of Surviving Lodgings and the Structure of the Respective Owners/Operators in WHS Localities

\begin{tabular}{|c|c|c|c|c|c|c|c|}
\hline \multirow{3}{*}{ Rural WHSs by types } & \multicolumn{3}{|c|}{$\begin{array}{l}\text { Structure and profile } \\
\text { of surviving lodgings }\end{array}$} & \multicolumn{4}{|c|}{$\begin{array}{c}\text { Structure of the respective } \\
\text { owners/operators*) }\end{array}$} \\
\hline & \multicolumn{2}{|c|}{ Pensions (\%) } & \multirow{2}{*}{$\begin{array}{l}\text { Profile as of } 2016 \\
\text { (all pensions) }\end{array}$} & \multicolumn{2}{|c|}{$\begin{array}{l}\text { Individual en- } \\
\text { terprises (\%) }\end{array}$} & \multicolumn{2}{|c|}{ LLCs**) (\%) } \\
\hline & 2005 & 2016 & & 2005 & 2016 & 2005 & 2016 \\
\hline The Danube Delta & 51.61 & 48.39 & $\begin{array}{l}9 \text { rooms; } 2 \text { stars; } \\
66.67 \% \text { no website }\end{array}$ & 21.71 & 17.39 & 69.57 & 73.91 \\
\hline The Dacian fortresses & 100.00 & 100.00 & $\begin{array}{c}3 \text { rooms; } 3 \text { stars; } \\
100.00 \% \text { no website }\end{array}$ & 100.00 & 100.00 & 0.00 & 0.00 \\
\hline The fortified churches & 100.00 & 100.00 & $\begin{array}{l}5 \text { rooms; } 2 \text { or } 3 \text { stars; } \\
100.00 \% \text { no website }\end{array}$ & 83.33 & 100.00 & 16.67 & 0.00 \\
\hline The churches of Moldavia & 86.67 & 80.00 & $\begin{array}{c}7 \text { rooms; } 2 \text { or } 3 \text { stars; } \\
58.33 \% \text { no website }\end{array}$ & 74.07 & 66.67 & 25.93 & 33.33 \\
\hline The wooden churches & 100.00 & 85.71 & $\begin{array}{c}4 \text { rooms; } 2 \text { stars; } \\
66.67 \% \text { no website }\end{array}$ & 92.86 & 84.62 & 7.14 & 15.38 \\
\hline Total rural WHSs & 76.83 & 70.73 & $\begin{array}{l}6 \text { rooms; } 2 \text { or } 3 \text { stars; } \\
78.33 \% \text { no website }\end{array}$ & 74.39 & 73.74 & 23.86 & 24.52 \\
\hline
\end{tabular}

*) It was not possible to sketch a profile for the owners/operators that continued their activity, due to the lack of information concerning equity capital, liabilities, number of employees and NACE codes of individual enterprises.

${ }^{* *}$ LLCS (Limited liability companies) is used for the Romanian SRLs (societati cu raspundere limitata)

Source: authors' calculations.

\section{Factors Influencing SSR and CR in Rural WHS Localities}

The general OLS regression equations for SSR and CR are:

$$
\begin{aligned}
& \text { SSR }=b_{0}+b_{1} \text { POINT }+b_{2} \text { LODG }+b_{3} \text { ROOM }+b_{4} \text { ARRIV }+ \\
& +b_{5} \text { OCCUP }+b_{6} \text { STAY }+b_{7} \text { OWNR }+b_{8} \text { POP }+b_{9} \text { POP } 2+\varepsilon_{i} \\
& \begin{aligned}
\text { CR }=b_{0}+b_{1} \text { POINT }+b_{2} \text { LODG }+b_{3} \text { ROOM }+b_{4} \text { ARRIV }+ \\
+b_{5} \text { OCCUP }+b_{6} \text { STAY }+b_{7} \text { OWNR }+b_{8} \text { POP }+b_{9} \text { POP } 2+\varepsilon_{i}
\end{aligned}
\end{aligned}
$$

The meaning of each abbreviation is presented in Appendix $B$.

Using stepwise regression, the models in Tables 9 and 10 were extracted based on their significance ( $p$-value). For SSR the most influential factors are: the ownership ratio and the tourist arrivals, followed by the total number of lodgings. For CR, the ownership ratio is less important. The introduction of the dummy variable, representing the existence of a local strategy for tourism development, decreases the model significance. When the workforce is also taken into consideration, the model significance decreases even further in both cases. The considered factors have a higher influence on the CR, explaining between $20 \%$ and $24.5 \%$ of this dependent variable.

Given the strong and significant correlation between SSR and CR, a new regression model was tested, including the $C R$ among the independent variables. The new general regression equation for SSR, including $C R$ as independent variable, is: 


$$
\begin{gathered}
\mathrm{SSR}_{\text {new }}=\mathrm{b}_{0}+\mathrm{b}_{1} \mathrm{CR}+\mathrm{b}_{2} \text { POINT }+\mathrm{b}_{3} \text { LODG } \mathrm{b}_{4} \text { ROOM }+\mathrm{b}_{5} \text { ARRIV }+\mathrm{b}_{6} \text { OCCUP }+\mathrm{b}_{7} \text { STAY }+ \\
+b_{8} \text { OWNR }+\mathrm{b}_{9} \text { POP }+\mathrm{b}_{10} \text { POP } 2+\varepsilon_{\mathrm{i}}
\end{gathered}
$$

Table 9. Selected Regression Models for SSR as Dependent Variable

\begin{tabular}{|l|c|c|c|c|c|c|}
\hline \multirow{2}{*}{$\begin{array}{c}\text { Independent } \\
\text { variables }\end{array}$} & \multicolumn{2}{c|}{ Model 1 } & \multicolumn{2}{c|}{ Model 3 } & \multicolumn{2}{c|}{ Model 4 } \\
\cline { 2 - 8 } & Estimate & T-statistic & Estimate & T-statistic & Estimate & T-statistic \\
\hline $\mathrm{b}_{0}$ & 0.3448 & 5.5424 & 0.3179 & 4.5651 & 0.3014 & 2.6874 \\
\hline LODG & 0.0203 & 0.9731 & 0.0167 & 0.7791 & 0.0174 & 0.7781 \\
\hline ARRIV & -0.0050 & -1.6331 & -0.0043 & -1.3610 & -0.0043 & -1.2881 \\
\hline OWNR & 0.3196 & 1.6357 & 0.3166 & 1.6103 & 0.3244 & 1.5711 \\
\hline POP2 & - & - & - & - & 0.1102 & 0.1917 \\
\hline DUMMY & - & - & 0.0845 & 0.8821 & 0.0788 & 0.7657 \\
\hline Adjusted R $\mathrm{R}^{2}$ (\%) & \multicolumn{3}{|c|}{19.23} & \multicolumn{2}{c|}{18.22} & \multicolumn{2}{c|}{13.31} \\
\hline p-value & \multicolumn{2}{|c|}{0.0788} & \multicolumn{2}{c|}{0.1162} & \multicolumn{2}{c|}{0.2050} \\
\hline
\end{tabular}

Source: authors' calculations.

Table 10. Selected Regression Models for CR as Dependent Variable

\begin{tabular}{|l|c|c|c|c|c|c|}
\hline \multirow{2}{*}{$\begin{array}{c}\text { Independent } \\
\text { variables }\end{array}$} & \multicolumn{2}{c|}{ Model 1 } & \multicolumn{2}{c|}{ Model 3 } & \multicolumn{2}{c|}{ Model 4 } \\
\cline { 2 - 8 } & Estimate & T-statistic & Estimate & T-statistic & Estimate & T-statistic \\
\hline $\mathrm{b}_{0}$ & 0.2856 & 5.3474 & 0.2629 & 4.3940 & 0.2234 & 2.3362 \\
\hline LODG & 0.0273 & 1.5230 & 0.0242 & 1.3172 & 0.0260 & 1.3614 \\
\hline ARRIV & -0.0054 & -2.0341 & -0.0048 & -1.7499 & -0.0046 & -1.6334 \\
\hline OWNR & 0.0905 & 0.5395 & 0.0880 & 0.5209 & 0.1066 & 0.6057 \\
\hline POP2 & - & - & - & - & 0.2637 & 0.5380 \\
\hline DUMMY & - & - & 0.0713 & 0.8667 & 0.0578 & 0.6583 \\
\hline Adjusted $R^{2}(\%)$ & \multicolumn{2}{|c|}{24.51} & \multicolumn{2}{c|}{23.45} & & 20.11 \\
\hline p-value & \multicolumn{2}{|c|}{0.0452} & \multicolumn{2}{c|}{0.0725} & & 0.1247 \\
\hline
\end{tabular}

Source: authors' calculations.

Using the stepwise regression, the models in Table 11 were selected based on their significance and similarity with the models in Tables 9 and 10. The explanatory power of the models increased to over $60 \%$, influenced mainly by the $C R$, while the influence of the other factors, with the exception of the ownership ratio, became insignificant. The introduction of the dummy variable and workforce continue to decrease the model significance.

Table 11. Selected Regression Models for Ssrnew as Dependent Variable

\begin{tabular}{|l|c|c|c|c|c|c|}
\hline \multirow{2}{*}{\begin{tabular}{c}
\multirow{2}{*}{$\begin{array}{c}\text { Independent } \\
\text { variables }\end{array}$} \\
\cline { 2 - 7 }
\end{tabular}} & Estimate & T-statistic & Estimate & T-statistic & Estimate & T-statistic \\
\hline $\mathrm{b}_{0}$ & 0.0837 & 1.3118 & 0.0807 & 1.2181 & 0.0979 & 1.1587 \\
\hline CR & 0.9140 & 5.2204 & 0.9021 & 4.9066 & 0.9108 & 4.7729 \\
\hline LODG & -0.0046 & -0.3277 & -0.0052 & -0.3537 & -0.0062 & -0.4058 \\
\hline ARRIV & -0.0001 & -0.0521 & -0.0001 & -0.0067 & -0.0001 & -0.0282 \\
\hline OWNR & 0.2369 & 1.8857 & 0.2373 & 1.8379 & 0.2273 & 1.6725 \\
\hline POP2 & - & - & - & - & -0.1300 & -0.3443 \\
\hline DUMMY & - & - & 0.0201 & 0.3161 & 0.0262 & 0.3860 \\
\hline Adjusted $\mathrm{R}^{2}$ (\%) & \multicolumn{2}{|c|}{67.15} & \multicolumn{2}{c|}{65.31} & & 63.29 \\
\hline p-value & \multicolumn{2}{|c|}{0.0001} & \multicolumn{2}{c|}{0.0003} & & 0.0010 \\
\hline
\end{tabular}

Source: authors' calculations. 
Table 12 presents the results for PCA while taking into consideration the same variables as those included in the selected models based on the stepwise regression. The PCA results confirm the decreasing explanatory power of the dummy variable (representing the existence or the absence of a tourism strategy) and of the workforce. PCA results further reveal that the influence of these two variables, mainly the workforce influence, is rather indirect through the second component. This suggests that the working population rather chooses to establish new economic entities (mainly individual enterprises) and relates through them with the existing entities, than to become directly employed by these. This situation further supports the idea of lifestyle enterprises owning the surviving lodgings.

Table 12. PCA Results for the Selected Variables as Resulted from Stepwise Regression

\begin{tabular}{|c|c|c|c|c|c|}
\hline \multicolumn{2}{|c|}{ PCA for $\mathbf{5}$ variables: $\mathbf{2}$ components extracted } & \multicolumn{3}{c|}{ Component weights } \\
\hline Component & Eigenvalue & Cumulative percentage & Variables & PC1 & PC2 \\
\hline 1 & 2.4917 & 49.83 & SSR & 0.5557 & 0.1670 \\
\hline 2 & 1.1158 & $\mathbf{7 2 . 1 5}$ & CR & 0.5575 & -0.0895 \\
\hline 3 & 0.7121 & 86.39 & LODG & 0.4086 & 0.0163 \\
\hline 4 & 0.5419 & 97.23 & ARRIV & -0.3983 & 0.5109 \\
\hline 5 & 0.1385 & 100.00 & OWNR & 0.1855 & 0.8384 \\
\hline \multicolumn{2}{|c|}{ PCA for $\mathbf{6}$ variables: $\mathbf{2}$ component extracted } & \multicolumn{3}{|c|}{ Component weights } \\
\hline Component & Eigenvalue & Cumulative percentage & Variables & PC1 & PC2 \\
\hline 1 & 2.7242 & 45.40 & SSR & 0.5168 & 0.2262 \\
\hline 2 & 1.1429 & $\mathbf{6 4 . 4 5}$ & CR & 0.5410 & -0.0188 \\
\hline 3 & 0.7481 & 76.92 & LODG & 0.3858 & 0.0523 \\
\hline 4 & 0.7049 & 88.66 & ARRIV & -0.3852 & 0.4468 \\
\hline 5 & 0.5419 & 97.69 & OWNR & 0.3453 & -0.2396 \\
\hline 6 & 0.1385 & 100.00 & DUMMY & 0.1542 & 0.8299 \\
\hline PCA for 7 variables: 2 components extracted & \multicolumn{4}{c|}{ Component weights } \\
\hline Component & Eigenvalue & Cumulative percentage & Variables & PC1 & PC2 \\
\hline 1 & 2.7532 & 39.33 & SSR & 0.5075 & -0.2016 \\
\hline 2 & 1.4154 & $\mathbf{5 9 . 5 5}$ & CR & 0.5388 & -0.0195 \\
\hline 3 & 0.8639 & 71.89 & LODG & 0.3714 & -0.2105 \\
\hline 4 & 0.7435 & 82.52 & ARRIV & -0.3905 & -0.2544 \\
\hline 5 & 0.5581 & 90.49 & OWNR & 0.1318 & -0.6254 \\
\hline 6 & 0.5299 & 98.06 & POP2 & 0.1308 & 0.6261 \\
\hline 7 & 0.1360 & 100.00 & DUMMY & 0.3567 & 0.2584 \\
\hline
\end{tabular}

Source: authors' calculations.

To complete the analysis performed through stepwise regression and PCA, which might have been influenced by the small number of observations (22), the IDA was introduced to investigate the processes influencing the number of bed places in surviving lodgings $(S B P)^{2}$. The following effects were defined:

1. $B P_{i}=$ the total number of bed places in each commune (an extensive factor);

2. $\mathrm{I}_{\mathrm{i}}=\mathrm{A}_{\mathrm{i}} / B \mathrm{~B}_{\mathrm{i}}$ - intensity effect; where $A$ represents the tourist arrivals in each commune;

\footnotetext{
2 Since SSR was calculated for the first time for 2016, and the number of surviving lodgings did not change between 2005 and 2016, the IDA was applied to the changes in bed places of the surviving lodgings.
} 
3. $\mathrm{S}_{\mathrm{i}}=\mathrm{OS} \mathrm{S}_{\mathrm{i}} / \mathrm{A}_{\mathrm{i}}$ - the length of stay; where OS represents the overnight stays in the respective commune lodgings (also an intensive factor);

4. $\mathrm{OR}_{\mathrm{i}}=\mathrm{NO}_{\mathrm{i}} / \mathrm{OWN} \mathrm{i}-$ the ownership ratio; where $\mathrm{NO}$ represents the total number of lodgings, and OWN represents the respective owners in each commune;

5. $I O c_{i}=O W N_{i} / O S_{i}-$ the inverse of a modified occupancy ratio;

6. $\quad \mathrm{IC}_{\mathrm{i}}=\mathrm{P}_{\mathrm{i}} / \mathrm{NO}_{\mathrm{i}}$ - the inverse of a modified carrying capacity, where $\mathrm{P}$ represents the population between 30 and 64 years in each commune;

7. $\mathrm{E}_{\mathrm{i}}=\mathrm{SBP}_{\mathrm{i}} / \mathrm{P}_{\mathrm{i}}$ - the employment opportunities for the population between 30 and 64 years; where SBP is the number of bed places in surviving lodgings in each commune.

The following equation describes the changes in the number of bed places in surviving lodgings:

$$
S B P=\sum_{i=1}^{n} B P_{i} \frac{A_{i}}{B P_{i}} \frac{O S_{i}}{A_{i}} \frac{N_{i}}{O W N_{i}} \frac{O W N_{i}}{O S_{i}} \frac{P_{i}}{N_{i}} \frac{S B P_{i}}{P_{i}}=\sum_{i} B P_{i} l_{i} S_{i} O R_{i} I O c_{i} I C c_{i} E_{i}
$$

The following formula describes the changes in the number of bed places in surviving lodgings:

$$
\Delta \mathrm{SBP}=\mathrm{SBP}^{2016}-\mathrm{SBP}^{2005}=\Delta \mathrm{SBF}_{\mathrm{BP}}+\Delta \mathrm{SBP}_{1}+\Delta \mathrm{SBP}_{\mathrm{S}}+\Delta \mathrm{SBP}_{\mathrm{OR}}+\Delta \mathrm{SBP}_{\mathrm{IOc}}+\Delta \mathrm{SBP}_{\mathrm{ICC}}+\Delta \mathrm{SBP}_{\mathrm{E}}
$$

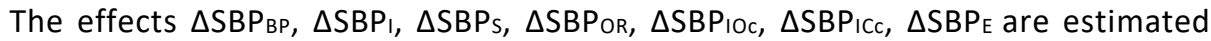
using the following formulas:

$$
\begin{gathered}
\Delta \mathrm{SBP}_{\mathrm{BP}}=\sum_{\mathrm{i}} \overline{\mathrm{SBP}_{\mathrm{i}}} \ln \left(\mathrm{BP}_{\mathrm{i}}^{2016} / \mathrm{BP}_{\mathrm{i}}^{2005}\right) \\
\Delta \mathrm{SBP}_{\mathrm{BP}}=\sum_{\mathrm{i}} \overline{\mathrm{SBP}_{\mathrm{i}}} \ln \left(\mathrm{BP}_{\mathrm{i}}^{2016} / \mathrm{BP}_{\mathrm{i}}^{2005}\right) \\
\Delta \mathrm{SBP}_{\mathrm{S}}=\sum_{\mathrm{i}} \overline{\mathrm{SBP}_{\mathrm{i}}} \ln \left(\mathrm{S}_{\mathrm{i}}^{2016} / \mathrm{S}_{\mathrm{i}}^{2005}\right) \\
\Delta \mathrm{SBP}_{\mathrm{OR}}=\sum_{\mathrm{i}} \overline{\mathrm{SBP}_{\mathrm{i}}} \ln \left(\mathrm{OR}_{\mathrm{i}}^{2016} / \mathrm{OR}_{\mathrm{i}}^{2005}\right) \\
\Delta \mathrm{SBP}_{\mathrm{IOC}}=\sum_{\mathrm{i}} \overline{\mathrm{SBP}_{\mathrm{i}}} \ln \left(\mathrm{IOc}_{\mathrm{i}}^{2016} / \mathrm{IOc}_{\mathrm{i}}^{2005}\right) \\
\Delta \mathrm{SBP}_{\mathrm{ICC}}=\sum_{\mathrm{i}} \overline{\mathrm{SBP}_{\mathrm{i}}} \ln \left(\mathrm{ICc}_{\mathrm{i}}^{2016} / \mathrm{ICc}_{\mathrm{i}}^{2005}\right) \\
\Delta \mathrm{SBP}_{\mathrm{E}}=\sum_{\mathrm{i}} \overline{\mathrm{SBP}_{\mathrm{i}}} \ln \left(\mathrm{E}_{\mathrm{i}}^{2016} / \mathrm{E}_{\mathrm{i}}^{2005}\right)
\end{gathered}
$$

where:

$$
\overline{\mathrm{SBP}}_{\mathrm{i}}=\frac{\mathrm{SBP}_{\mathrm{i}}^{2016}-\mathrm{SBP}_{\mathrm{i}}^{2005}}{\operatorname{lnSBP_{\mathrm {i}}^{2016}-\operatorname {InSBP}} \mathrm{i}_{\mathrm{i}}^{2005}}
$$

The following formula describes the changes in multiplicative form:

$$
\mathrm{R}=\mathrm{SBP}^{2016} / \mathrm{SBP}^{2005}=\mathrm{R}_{\mathrm{BP}} \mathrm{R}_{\mathrm{I}} \mathrm{R}_{\mathrm{S}} \mathrm{R}_{\mathrm{OR}} \mathrm{R}_{\mathrm{IOC}} \mathrm{R}_{\mathrm{ICC}} \mathrm{R}_{\mathrm{E}}
$$

where the effects are calculated based on the following formulas:

$$
\begin{aligned}
& \mathrm{R}_{\mathrm{BP}}=\exp \left(\sum_{\mathrm{i}}\left(\overline{\mathrm{SBP}}_{\mathrm{i}} / \overline{\mathrm{SBP}}\right) \ln \left(\mathrm{BP}_{\mathrm{i}}^{2016} / \mathrm{BP}_{\mathrm{i}}^{2005}\right)\right) \\
& \mathrm{R}_{\mathrm{l}}=\exp \left(\sum_{\mathrm{i}}\left(\overline{\mathrm{SBP}}_{\mathrm{i}} / \overline{\mathrm{SBP}}\right) \ln \left(\mathrm{I}_{\mathrm{i}}^{2016} / \mathrm{I}_{\mathrm{i}}^{2005}\right)\right) \\
& \mathrm{R}_{\mathrm{S}}=\exp \left(\sum_{\mathrm{i}}(\overline{\mathrm{SBP}} \mathrm{i} / \overline{\mathrm{SBP}}) \ln \left(\mathrm{S}_{\mathrm{i}}^{2016} / \mathrm{S}_{\mathrm{i}}^{2005}\right)\right) \\
& \mathrm{R}_{\mathrm{OR}}=\exp \left(\sum_{\mathrm{i}}\left(\overline{\mathrm{SBP}_{\mathrm{i}}} / \overline{\mathrm{SBP}}\right) \ln \left(\mathrm{OR}_{\mathrm{i}}^{2016} / \mathrm{OR}_{\mathrm{i}}^{2005}\right)\right) \\
& \mathrm{R}_{\mathrm{IOC}}=\exp \left(\sum_{\mathrm{i}}\left(\overline{\mathrm{SBP}}_{\mathrm{i}} / \overline{\mathrm{SBP}}\right) \ln \left(\mathrm{IOc}_{\mathrm{i}}^{2016} / \mathrm{IOc}_{\mathrm{i}}^{2005}\right)\right) \\
& \mathrm{R}_{\mathrm{ICC}}=\exp \left(\sum_{\mathrm{i}}\left(\overline{\mathrm{SBP}}_{\mathrm{i}} / \overline{\mathrm{SBP}}\right) \ln \left(\mathrm{ICc}_{\mathrm{i}}^{2016} / \mathrm{ICc}_{\mathrm{i}}^{2005}\right)\right) \\
& \mathrm{R}_{\mathrm{E}}=\exp \left(\sum_{\mathrm{i}}\left(\overline{\mathrm{SBP}_{\mathrm{i}}} / \overline{\mathrm{SBP}}\right) \ln \left(\mathrm{E}_{\mathrm{i}}^{2016} / \mathrm{E}_{\mathrm{i}}^{2005}\right)\right)
\end{aligned}
$$


The results of the decompositions are presented in Tables 13 (additive) and 14 (multiplicative). The data confirm the influence on the changes of surviving bed places of the total lodgings via total bed places (BP), the negative influence of tourist arrivals via the intensity effect (I) and the low influences of ownership ratio (OR) and workforce via the employment opportunities (E).

Table 13. Additive Decomposition for the Changes in the Surviving Bed Places Between 2005 and 2016

\begin{tabular}{|l|r|c|r|r|r|r|}
\hline $\begin{array}{c}\text { Changes in } \\
\text { additive form }\end{array}$ & $\begin{array}{c}\text { The Dan- } \\
\text { ube Delta }\end{array}$ & $\begin{array}{c}\text { The Dacian } \\
\text { fortresses }\end{array}$ & $\begin{array}{c}\text { The fortified } \\
\text { churches }\end{array}$ & $\begin{array}{c}\text { The churches } \\
\text { of Moldavia }\end{array}$ & $\begin{array}{c}\text { The wooden } \\
\text { churches }\end{array}$ & $\begin{array}{c}\text { Total rural WHSs (based on } \\
\text { data by communes) }\end{array}$ \\
\hline$\Delta \mathrm{SBP}$ & 297 & $n / a$ & 9 & -409 & 37 & $\mathbf{- 6 6}$ \\
\hline$\Delta \mathrm{SBP}_{\mathrm{BP}}$ & 877 & $\mathrm{n} / \mathrm{a}$ & 38 & 35 & 13 & $\mathbf{9 6 2}$ \\
\hline$\Delta \mathrm{SBP}_{\mathrm{I}}$ & -562 & $\mathrm{n} / \mathrm{a}$ & 93 & 664 & 288 & $\mathbf{4 8 1}$ \\
\hline$\Delta \mathrm{SBP}_{\mathrm{S}}$ & 311 & $\mathrm{n} / \mathrm{a}$ & -20 & -65 & -92 & $\mathbf{1 3 3}$ \\
\hline$\Delta \mathrm{SBP}_{\mathrm{OR}}$ & 180 & $\mathrm{n} / \mathrm{a}$ & 12 & 115 & 6 & $\mathbf{3 1 3}$ \\
\hline$\Delta \mathrm{SBP}_{\mathrm{IOC}}$ & 257 & $\mathrm{n} / \mathrm{a}$ & -112 & -549 & -245 & $\mathbf{- 6 4 9}$ \\
\hline$\Delta \mathrm{SBP}_{\mathrm{ICC}}$ & -1018 & $\mathrm{n} / \mathrm{a}$ & -4 & -46 & 29 & $\mathbf{- 1 0 3 6}$ \\
\hline$\Delta \mathrm{SBP}_{\mathrm{E}}$ & 252 & $\mathrm{n} / \mathrm{a}$ & 2 & -561 & 39 & $\mathbf{- 2 7 0}$ \\
\hline
\end{tabular}

Source: authors' calculations.

Table 14. Multiplicative Decomposition for the Changes in the Surviving Bed Places Between 2005 and 2016

\begin{tabular}{|l|r|c|r|r|r|r|}
\hline $\begin{array}{l}\text { Changes in mul- } \\
\text { tiplicative form }\end{array}$ & $\begin{array}{r}\text { The Dan- } \\
\text { ube Delta }\end{array}$ & $\begin{array}{c}\text { The Dacian } \\
\text { fortresses }\end{array}$ & $\begin{array}{c}\text { The fortified } \\
\text { churches }\end{array}$ & $\begin{array}{c}\text { The churches } \\
\text { of Moldavia }\end{array}$ & $\begin{array}{c}\text { The wooden } \\
\text { churches }\end{array}$ & $\begin{array}{c}\text { Total rural WHSs (based on } \\
\text { data by communes) }\end{array}$ \\
\hline $\mathrm{R}$ & 1.3644 & $\mathrm{n} / \mathrm{a}$ & 1.2500 & 0.5583 & 1.3978 & $\mathbf{0 . 9 6 4 7}$ \\
\hline $\mathrm{R}_{\mathrm{BP}}$ & 0.9176 & $\mathrm{n} / \mathrm{a}$ & 0.9608 & 0.0502 & 0.1170 & $\mathbf{0 . 5 2 3 7}$ \\
\hline $\mathrm{R}_{\mathrm{I}}$ & -0.5877 & $\mathrm{n} / \mathrm{a}$ & 2.3083 & 0.9459 & 2.6022 & $\mathbf{0 . 2 6 2 0}$ \\
\hline $\mathrm{R}_{\mathrm{S}}$ & 0.3257 & $\mathrm{n} / \mathrm{a}$ & -0.4925 & -0.0946 & -0.8327 & $\mathbf{0 . 0 7 2 6}$ \\
\hline $\mathrm{R}_{\mathrm{OR}}$ & 0.1883 & $\mathrm{n} / \mathrm{a}$ & 0.2978 & 0.1642 & 0.0564 & $\mathbf{0 . 1 7 0 6}$ \\
\hline $\mathrm{R}_{\mathrm{IOC}}$ & 0.2693 & $\mathrm{n} / \mathrm{a}$ & -2.7859 & -0.7830 & -2.2194 & $\mathbf{- 0 . 3 5 3 4}$ \\
\hline $\mathrm{R}_{\mathrm{ICC}}$ & -1.0654 & $\mathrm{n} / \mathrm{a}$ & -0.1031 & -0.0659 & 0.2647 & $\mathbf{- 0 . 5 6 4 5}$ \\
\hline $\mathrm{R}_{\mathrm{E}}$ & 0.2637 & $\mathrm{n} / \mathrm{a}$ & 0.0378 & -0.7996 & 0.3467 & $\mathbf{- 0 . 1 4 6 9}$ \\
\hline
\end{tabular}

Source: authors' calculations.

\section{RESULTS AND DISCUSSION}

According to Table 1, Romania appears unable to capitalize on the presence of 8 WHSs. This situation is contradicting the ideas regarding the power of WHSs to promote the host country and to attract an increased number of tourists. The recent study of latu et al. (2018) confirms Romania's position and its low ability to use WHSs in developing tourism. The only positive aspect is that Romanian rural WHSs are not plagued by excessive visitation and still have the time to envisage proper site management in order to avoid this problem.

Table 2 shows the relative lack of information describing the WHSs and the absence of links to the UNESCO pages related to the respective WHSs, 19 of 32 communes not mentioning the presence of WHSs on their websites. This situation is in line with the findings of Poria et al. (2011) which consider that the local awareness regarding the meaning of WHS designation is, at best, low to moderate. 
The data in Table 3 appear to confirm the idea that the tourist attractions represented by WHSs seem to have an influence on the lodging growth rate. Overall, it seems that WHSs enhance the attractiveness of their host localities. However, the low growth rate for the Danube Delta, the low occupancy rates for the majority of cultural WHS localities and the decrease in the length of stay suggest that the accommodation facilities should be supplemented by various entertainment offers in order to increase the number of tourists and their length of stay.

The data regarding the population indicate that the rural economies of these WHS localities can support the local population and there was less migration toward domestic urban areas or foreign countries. There are not enough data to assess the tourism contribution to these local rural economies, though an educated guess indicated that a contribution exists, the unknown being the size of this contribution.

The SSR for the rural WHS localities included in this study is of $38.68 \%$ (Table 7), lower than the SSR reported by Pop and Balint (2017) for the rural WHSs hosting at least ten lodgings. This was due to the inclusion of localities with less than ten lodgings, where the SSR is generally smaller due to low tourist flows. Nonetheless, it should be pointed out that the overall SSR for the rural WHS localities is slightly higher that the SSR reported by Pop and Balint (2017) for all the rural localities with at least ten lodgings, of $38.21 \%$.

The surviving lodging profile in Table 8 shows that the accommodation units are of small capacity, providing services for budget and mid-market tourists and most of them have no websites, selling their services mostly via various booking websites.

Table 8 also shows the lack of diversification or a low diversification of lodging facilities, with the exception of rural Danube Delta localities. The dominance of individual enterprises is also high, with the exception of the Danube Delta.

The information in Table 8 and Table 4 suggests that the economic entities owning the surviving lodgings are rather lifestyle enterprises, operating the respective accommodation facilities to complement other (economic) activities.

The results in Tables 9, 10 and 11 suggest that SSR is mainly influenced by the continuity rate $(C R)$ and the ownership ratio. Through $C R$, SSR is indirectly influenced by the number of lodgings (representing the overall competition) and tourist arrivals.

It is interesting to mention that tourist arrivals have a negative influence on SSR, indicating a decrease when the number of arrivals increases. This odd situation suggests two aspects: the fact that relatively small surviving lodgings are not prepared to receive constantly a high number of tourists without decreasing the quality of their services and/or the existence of informal accommodation facilities which by attracting tourists have a negative impact on the SSR of registered accommodation.

It is also worth mentioning that the tourist potential (expressed in points) has no influence on CR and, therefore on SSR, while the existence or the absence of a local strategy for tourism development decreased the explanatory power of any selected model.

These findings extracted from regression models confirm the suggestion expressed based on Table 8 and Table 4 data, that the economic entities operating lodgings in WHS localities are rather lifestyle enterprises. Not being influenced by the existing workforce indicates that these entities do not create many employment opportunities. Since the ownership ratio is close to 1 , this suggests that for the respective entities is important to own and operate one accommodation facility. 
Not being influenced either by the tourist potential or by the existence of a strategy, the initiative of owning and operating a tourist lodging appears to be an individual decision based on the personal assessment of the local economic environment. Furthermore, this lack of influence combined with the absence of significant information on the WHS localities websites regarding the presence of WHSs and their attractivity, seems to confirm the suggestions of international research regarding the lack of awareness regarding the importance of WHSs (Poria et al. 2011) among the local community or at least among their representatives.

PCA results (Table 12) confirm the negative direct influence of tourist arrivals, revealed through the regression models. Additionally, PCA results endorse the findings in Tables 9 and 10 regarding the strong relationship between SSR, CR, and the number of lodgings, tourist arrivals and ownership ratio. PCA results also support the idea of lifestyle enterprises owning the surviving lodgings.

The results of IDA (Table 13 and 14) support the results of regression analysis and PCA analysis.

\section{CONCLUSIONS}

This article investigated the role of rural WHSs in local rural tourism development in Romania, adding to the existing body of literature the idea that the presence of a WHS in rural areas is not a panacea for promoting tourism.

A positive influence was identified, Romanian rural localities hosting WHSs appear to have an advantage over regular communes since they experienced a higher lodging and room growth rates and also attracted more tourists (mostly domestic) compared to similar domestic destinations. Also, the retention of the population within these localities is higher compared to an overall decrease in Romanian rural population. Furthermore, the SSR within these rural WHS localities is similar to the overall SSR reported by Pop and Balint (2017) for the rural localities with at least ten lodging facilities and $10 \%$ higher than for the rural localities with no well-known tourist attractions. Therefore, a SSR over $35 \%$ for a decade (2005-2016) can be considered satisfactory and encouraging within the intricate Romanian business environment. The levels of SSR and CR point out that there exist an economic sustainability of the accommodation and the respective economic entities.

However, at a closer look, the low level of occupancy rates and length of stays, combined with a low carrying capacity indicate there is a long way ahead for further tourism development within Romanian rural WHS localities. Most of them are far from achieving their tourism potential and do not experience overcrowding. What these localities lack are: a) a more diverse offer of accommodation facilities catering for various types of tourists; b) a varied range of alternative entertainment facilities, including packages presenting the intangible, cultural heritage (local apparel, art, historical reenactments, as suggested by Yi et al. (2018)) which might increase the length of stay and the occupancy rate. The scarcity of entertainment facilities in WHS localities was also highlighted by Pop and Coros (2016).

Given this situation, the factors influencing the SSR and CR were investigated. The ownership ratio (close to 1 ) and the number of other lodgings have a positive influence suggesting that to those operating the lodging facilities it is important to own the respective lodging, while the presence of other competitors stimulate their efforts to survive. On the other hand, tourist arrivals have a negative influence, indicating two problems: 
a) the surviving lodgings low capacity to deal with a constant flow of tourism; b) the presence of a hidden competition represented by informal lodgings, discussed by RadanGorska (2013). It is worth mentioning the low relationship with the existing workforce, combined with the low ownership rate, low occupancy rate, the absence of websites and the dominance of individual enterprises. These point toward lifestyle enterprises, creating few employment opportunities. This situation has already been confirmed for WHS Danube Delta by Pop and Coros (2018). Therefore, the population retention within WHS localities is little influenced by the survival of the lodging facilities.

It is also interesting to mention that the existence or absence of a local strategy for tourism development decreased the explanatory power of the models and have rather an indirect influence on SSR and CR. This situation points toward two outcomes: a) that the tourism developments between 2005 and 2016 in WHS localities was based mainly on individual decisions which later on became modest local initiatives; b) combined with the modest amount of information regarding their respective WHSs on the communes websites and the amateurish way this information is presented, it can be safely said that there is a low to moderate awareness level (at least at the levels of local authorities) regarding the tourist potential of WHSs.

While some exceptions exist, like the case of Viscri presented by lorio and Corsale (2014), the majority of Romanian WHS localities do not properly exploit their tourist potential, a situation confirmed by latu et al. (2018). In the cases of three communes (out of the 32 investigated), the local communities appear not to be willing to host tourists, having no registered lodging in 2005 and 2016, situation also pointed out by Pop and Coros (2016).

Nonetheless, the current low development of tourism in most of Romanian rural WHS localities can be the base for further sustainable tourism development which might avoid excessive visitations and the deterioration of the cultural and natural environment. Though, at the central level, the authorities must recognize the special status of rural WHS localities and create a general framework that will encourage the local initiatives (including, as discussed by Jimura (2011), local tourist associations involved in WHS site management) for a sustainable and authentic tourism development, preserving the cultural and natural heritage.

The limitations of this study are caused by a relative short series of data and by the absence of more comprehensive information regarding the presence of informal accommodation facilities in rural areas.

The presented research opens the door for further studies on tourism demand and tourism governance for the WHS localities in order to help the local governments to develop authentic and sustainable tourism for these areas.

\section{REFERENCES}

Adie, B.A., \& Hall, C.M. (2017). Who visits World Heritage? A comparative analysis of three cultural sites. Journal of Heritage Tourism, 12(1), 67-80. https://doi.org/10.1080/1743873X.2016.1151429

Altunel, M.C., \& Erkut, B. (2015). Cultural tourism in Istanbul: The mediation effect of tourist experience and satisfaction on the relationship between involvement and recommendation intention. Journal of Destination Marketing \& Management, 4(4), 213-221. https://doi.org/10.1016/j.jdmm.2015.06.003

Ang, B.W. (2005). The LMDI approach to decomposition analysis: A practical guide. Energy Policy, 33, 867-871. https://doi.org/10.1016/j.enpol.2003.10.010 
Arezki, R., Piotrowski, J.M., \& Cherif, R. (2009). Tourism Specialization and Economic Development: Evidence from the UNESCO World Heritage List, IMF Working Papers 09/176, International Monetary Fund.

Balezentis, T., Krisciukaitiene, I., Balezentis, A., \& Garland, R. (2012). Rural tourism development in Lithuania (2003-2010) - A quantitative analysis. Tourism Management Perspectives, 2-3, 1-6. https://doi.org/10.1016/j.tmp.2012.01.001

Bordanc, F., \& Turnock, D. (1997). Eco-tourism and the Small Family Farms of the Romanian Carpathians. Geographica Pannonica, 1, 32-36.

Boyd, S.W., \& Timothy, D.J. (2006). Marketing Issues and World Heritage Sites. In A. Leask \& A. Fyall (Eds.), Managing World Heritage Sites (pp. 53-68). Oxford, UK: Butterworth-Heinemann. https://doi.org/10.1016/B978-0-7506-6546-9.50013-7

Breakey, N.M. (2012). Study in of world heritage visitors: The case of the remote Riversleigh Fossil Site. Visitor Studies, 15(1), 82-97. https://doi.org/10.1080/10645578.2012.660845

Caust, J., \& Vecco, M. (2017). Is UNESCO world heritage recognition a blessing or burden? Evidence from developing Asian countries. Journal of Cultural Heritage, 27, 1-9. https://doi.org/10.1016/j.culher.2017.02.004

Cellini, R. (2011). Is UNESCO recognition effective in fostering tourism? A comment on Yang, Lin and Han. Tourism Management, 32(2), 452-454. https://doi.org/10.1016/j.tourman.2010.01.018

Chi, C.G., Cai, R., \& Li, Y. (2017). Factors influencing residents' subjective well-being at World Heritage Sites. Tourism Management, 63, 209-222. https://doi.org/10.1016/j.tourman.2017.06.019

Corsale, A., \& lorio, M. (2014). Transylvanian Saxon culture as heritage: Insights from Viscri, Romania. Geoforum, 52, 22-31. https://doi.org/10.1016/j.geoforum.2013.12.008

Cuccia, T., \& Rizzo, I. (2013). Seasonal tourism flows in UNESCO sites: the case of Sicily. In J. Kaminsky, A.M. Benson \& D. Arnold (Eds.), Contemporary issues in Cultural heritage tourism (pp. 179-199). London: Routledge.

Cuccia, T., Guccio, C., \& Rizzo, I. (2016). The effects of UNESCO World Heritage List inscription on tourism destination performance in Italian regions. Economic Modelling, 53, 494-508. https://doi.org/10.1016/j.econmod.2015.10.049

Cunha, C., Kastenholz, E., \& Carneiro, M.J. (2018). Lifestyle entrepreneurs: the case of rural tourism. In L.C. Carvalho, C. Rego, M.R. Lucas, M.I. Sanchez-Hernandez \& A.B. Noronha (Eds.), Entrepreneurship and structural change in dynamic territories (pp. 175-188). Switzerland: Springer. https://doi.org/10.1007/978-3-319-76400-9_10

Frey, B.S., Pamini, P., \& Steiner, L. (2013). Explaining the World Heritage List: An empirical study. International Review of Economics, 60(1), 1-19. https://doi.org/10.1007/s12232-013-0174-4

Fyall, A., \& Rakic, T. (2006). The future market for world heritage sites. In A. Leask \& A. Fyall (Eds.), Managing world heritage sites (pp. 159-175). Oxford, UK: Butterworth-Heinemann. https://doi.org/10.1016/B978-0-7506-6546-9.50022-8

Hall, D. (2000). Sustainable Tourism Development and Transformation in Central and Eastern Europe. Journal of Sustainable Tourism, 8(6), 441-457. https://doi.org/10.1080/09669580008667379

Hall, D. (2004). Rural Tourism Development in Southeastern Europe: Transition and the Search for Sustainability. International Journal of Tourism Research, 6, 165-176. https://doi.org/10.1002/jtr.482

Huang, C.H., Tsaur, J.R., \& Yang, C.H. (2012). Does world heritage list really induce more tourists? Evidence from Macau. Tourism Management, 33(6), 1450-1457. https://doi.org/10.1016/j.tourman.2012.01.014

latu, C., Ibanescu, B.C., Stoleriu, O.M., \& Munteanu, A. (2018). The WHS designation - a factor of sustainable tourism growth for Romanian rural areas?. Sustainability, 10(3), 626.

Iorio, M., \& Corsale, A. (2010). Rural tourism and livelihood strategies in Romania. Journal of Rural Studies, 26(2), 152-162. https://doi.org/10.1016/j.jrurstud.2009.10.006 
Iorio, M., \& Corsale, A. (2013). Community-based tourism and networking: Viscri, Romania. Journal of Sustainable Tourism, 22(2), 234-255. https://doi.org/10.1080/09669582.2013.802327

Jaafar, M., Noor, S., \& Rasoolimanesh, S. (2015). Perception of young local residents toward sustainable conservation programmes: A case study of the Lenggong world cultural heritage site. Tourism Management, 48, 154-163. https://doi.org/10.1016/j.tourman.2014.10.018

Jimura, T. (2008). The impact of world heritage site designation on local communities - A case study of Ogimachi, Shirakawa-mura, Japan. Tourism Management, 32(2), 288-296. https://doi.org/10.1016/j.tourman.2010.02.005

Jones, T.E., Yang, Y., \& Yamamoto, K. (2017). Assessing the recreational value of world heritage site inscription: A longitudinal travel cost analysis of Mount Fuji climbers. Tourism Management, 60, 67-78. https://doi.org/10.1016/j.tourman.2016.11.009

Kastenholz, E., \& Sparrer, M. (2009). Rural dimensions of the commercial home. In P. Lynch, A.J. McIntosh \& H. Tucker (Eds.), Commercial homes in tourism: An international perspective (pp. 138-149). London: Routledge.

Landorf, C. (2009). Managing for sustainable tourism: a review of six cultural World Heritage Sites. Journal of Sustainable Tourism, 17(1), 53-70. https://doi.org/10.1080/09669580802159719

Latkova, P., \& Vogt, C. (2012). Residents' attitudes toward existing and future tourism development in rural communities. Journal of Travel Research, 51(1), 50-67. https://doi.org/10.1177/0047287510394193

Li, M., Wu, B., \& Cai, L. (2008). Tourism development of world heritage sites in China: a geographical perspective. Tourism Management, 29(2), 308-319. https://doi.org/10.1016/j.tourman.2007.03.013

Nguyen, T.H.H., \& Cheung, C. (2014). The classification of heritage visitors: A case of Hue City, Vietnam. Journal of Heritage Tourism, 9(1), 35-50. https://doi.org/10.1080/1743873X.2013.818677

Nicholas, L., \& Thapa, B. (2010). Visitor perspectives on sustainable tourism development in the pitons management area world heritage site, St. Lucia. Environment, Development and Sustainability, 12(5), 839-857. https://doi.org/10.1007/s10668-009-9227-y

Pop, C., \& Coros, M.M. (2016). Romanian Rural Tourism and the UNESCO Heritage Sites. In T. Paduraru \& G. Tacu (Eds.), Romanian Rural Tourism in the Context of Sustainable Development. Present and Prospects (pp. 67-81). Iași: Performantica, volume XL.

Pop, C., \& Coros, M.M. (2018). The Survival of accommodation Facilities and the Respective Owners/Operators in Rural Danube Delta. In T. Paduraru, D. Ungureanu \& G. Tacu (Eds.), Romanian Rural Tourism in the Context of Sustainable Development. Present and Prospects (pp. 63-73). Iași: Performantica, volume XLIV.

Pop, C., Coros, M.M., \& Balint, C. (2017). Romanian rural tourism: a survey of accommodation facilities. Studia UBB Negotia, 62(2), 71-126. https://doi.org/10.24193/subbnegotia.2017.2.05

Pop, C., \& Balint, C. (2017). Romanian rural lodgings: how many survived over a decade? A preliminary study focused on the rural localities hosting 10 or more accommodation units. Studia UBB Negotia, 62(3), 69-96. https://doi.org/10.24193/subbnegotia.2017.3.04

Poria, Y., Reichel, A., \& Cohen, R. (2011). World heritage site - is it an effective brand name? A case study of a religious heritage site. Journal of Travel Research, 50(5), 482-495. https://doi.org/10.1177/0047287510379158

Poria, Y., Reichel, A., \& Cohen, R. (2013). Tourist perceptions of World Heritage Site and its designation. Tourist Management, 35, 272-274. https://doi.org/10.1016/j.tourman.2012.02.011

Radan-Gorska, M.M. (2013). Destinations without regulations: informal practices in Romanian rural tourism. Journal of Comparative Research in Anthropology and Sociology, 4(2), 195-225. 
Rasoolimanesh, S.M., Jaafar, M., Ahmad, A.G., \& Bairghi, R. (2017). Community participation in World Heritage Site conservation and tourism development. Tourism Management, 58, 142153. https://doi.org/10.1016/j.tourman.2016.10.016

Reyes, V. (2014). The production of cultural and natural wealth: An examination of World Heritage Sites. Poetics, 44, 42-63. https://doi.org/10.1016/j.poetic.2014.04.003

Richards, G. (2011). Creativity and Tourism - The State of the Art. Annals of Tourism Research, 38(4), 1225-1253. https://doi.org/10.1016/j.annals.2011.07.008

Santa-Cruz, F.G., \& Lopez-Guzman, T. (2017). Culture, tourism and World Heritage Sites. Tourism Management Perspectives, 24, 111-116. https://doi.org/10.1016/j.tmp.2017.08.004

Su, Y.W., \& Lin, H.L. (2014). Analysis of international tourist arrivals worldwide. The role of world heritage sites. Tourism Management, 40, 46-58. https://doi.org/10.1016/j.tourman.2013.04.005

Su, M., \& Wall, G. (2014). Community participation in tourism at a world heritage site: Mutianyu Great Wall, Beijing, China. International Journal of Tourism Research 16(2), 146-156. https://doi.org/10.1002/jtr.1909

Timothy, D.J. (2011). Cultural heritage and tourism: An introduction. Bristol, UK: Channel View Publications.

Turnock, D. (1991). Romanian villages: rural planning under communism. Rural History, 2(1), 81-112. https://doi.org/10.1017/S0956793300002636

Turnock, D. (1996). The rural transition in Romania. Eastern European Countryside, 2, 45-57. Retrieved on October 20, 2018 from http://www.home.umk.pl/ eec/wp-content/uploads/1996_6_Turnock.pdf

Turnock, D. (1999). Sustainable rural tourism in the Romanian Carpathians. The Geographical Journal, 165(2), 192-199. https://doi.org.10.2307/3060417

Ung, A., \& Vong, T.N. (2010). Tourist experience of heritage tourism in Macau SAR, China. Journal of Heritage Tourism, 5(2), 157-168. https://doi.org/10.1080/17438731003668502

Yang, C.H., Lin, H.L., \& Han, C.C. (2010). Analysis of international tourist arrivals in China. The role of World Heritage Sites. Tourism Management, 31(6), 827-837. https://doi.org/10.1016/j.tourman.2009.08.008

Yang, C.H., \& Lin, H.L. (2014). Revisiting the relationships between World Heritage Sites and tourism. Tourism Economics, 20(1), 73-86. https://doi.org/10.5367/te.2013.0359

Yi, X., Fu, X., Yu, L., \& Jiang, L. (2018). Authenticity and loyalty at heritage sites: The moderation effect of postmodern authenticity. Tourism Management, 67, 411-424. https://doi.org/10.1016/j.tourman.2018.01.013 


\section{Appendix A: Map of Romanian WHSs}

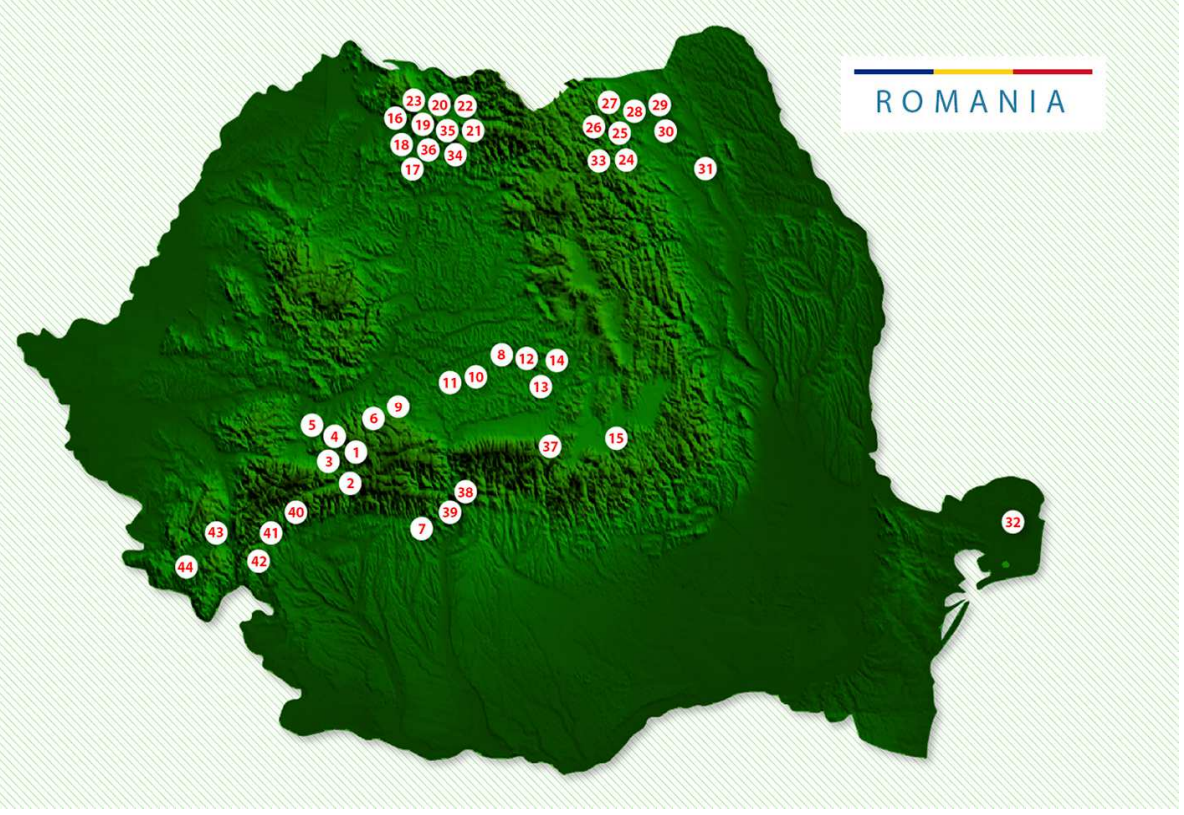

\section{Map legend}

1. Sarmisegetusa Regia Dacian site (rural)

2. Banita Dacian site (rural)

3. Piatra Rosie Dacian site (rural)

4. Costesti Dacian site (rural)

5. Blidaru Dacian site (rural)

6. Capalna Dacian site (rural)

7. Horezu Monastery (urban)

8. Sighisoara citadel and city center (urban)

9. Calnic village - fortified church (rural)

10. Biertan village - fortified church (rural)

11. Valea Viilor village - fortified church (rural)

12. Saschiz village - fortified church (rural)

13. Viscri village - fortified church (rural)

14. Darjiu village - fortified church (rural)

15. Prejmer village - fortified church (rural)

16. Surdesti wooden church (rural)

17. Rogoz wooden church (urban)
18. Plopis wooden church (rural)

19. Budesti wooden church (rural)

20. Poienile Izei wooden church (rural)

21. Deal leud wooden church (rural)

22. Barsana wooden church (rural)

23. Desesti wooden church (rural)

24. Voronet monastery (urban)

25. Humor monastery (rural)

26. Moldovita monastery (rural)

27. Sucevita monastery (rural)

28. Arbore monastery (rural)

29. Patrauti church (rural)

30. Probota monastery (urban)

31. Suceava St.George church (urban)

32. Danube Delta (rural)

33-44. Ancient and primeval beech forest (rural)

Source: www.uncover-romania.com/attractions/unesco-heritage-romania/ 
Appendix B: Descriptive Statistics of Variables Under Analysis

\begin{tabular}{|c|c|c|c|c|c|c|}
\hline Variables & Average & Median & St.deviation & Minimum & Maximum & Count \\
\hline SSR & 37.18 & 34.41 & 21.59 & 0.00 & 81.82 & 22 \\
\hline CR & 29.17 & 31.29 & 19.17 & 0.00 & 66.67 & 22 \\
\hline POINT & 38.45 & 37.90 & 9.90 & 22.54 & 54.53 & 22 \\
\hline LODG & 144.75 & 77.78 & 217.03 & -72.73 & 733.33 & 22 \\
\hline ROOM & 267.52 & 112.84 & 504.05 & -45.83 & $1,900.00$ & 22 \\
\hline ARRIV & 830.72 & 156.69 & 146.13 & -81.26 & $4,608.16$ & 22 \\
\hline OCCUP & 130.71 & 46.56 & 238.52 & -56.54 & $1,044.13$ & 22 \\
\hline STAY & -27.27 & 0.00 & 47.35 & -85.00 & 26.19 & 22 \\
\hline OWNR & 12.30 & 6.71 & 22.23 & -24.81 & 75.00 & 22 \\
\hline POP & -3.73 & -5.03 & 7.52 & -16.93 & 11.00 & 22 \\
\hline POP2 & 14.23 & 12.22 & 8.33 & 4.93 & 41.36 & 22 \\
\hline
\end{tabular}

SSR is the simple survival rate (\%); CR is the continuity rate for the owners/operators (\%); POINT is the number of points representing the tourist potential according to PNDR; LODG is the change in the number of lodgings between 2005 and 2016 (\%); ROOM is the change in the number of rooms between 2005 and 2016 (\%); ARRIV is the change in the number of arrivals between 2005 and 2016 (\%); OCCUP is the change in the occupancy rate between 2005 and 2016 (\%); STAY is the change in the length of stay between 2005 and 2016 (\%); OWNR is the change in the ownership ratio between 2005 and 2016 (\%); POP is the change in total population between 2005 and 2016 (\%); POP2 is the change in the percentage of the population of 30 to 64 years between 2005 and 2016 (\%). There is a dummy variable introduced for the existence (1) or the absence (0) of a strategy including tourism at the commune level. 


\section{Authors}

The contribution share of authors is equal and amounted to $50 \%$ each of them.

\section{Cornelia Pop}

Doctor in Finance (Babes-Bolyai University, Cluj-Napoca, Romania). Professor of Hotel Development, International Investments and International Finance (Babes-Bolyai University, Cluj-Napoca, Romania). Her research interests include: hospitality \& tourism, World Heritage Sites, frontier markets, FDIs.

Correspondence to: Cornelia Pop, PhD, Babes-Bolyai University of Cluj-Napoca, Faculty of Business, 7 Horea Str., Cluj Napoca, Romania, e-mail: conelia.pop@tbs.ubbcluj.ro

ORCID (ib http://orcid.org/0000-0002-8912-4303

\section{Maria-Andrada Georgescu}

Doctor in Finance (Babes-Bolyai University, Cluj-Napoca, Romania). Associate Professor of Public Finance, Financial Instruments of Government and Budget and Taxation in EU (University of Political Studies and Public Administration). Her research interests include financial analysis and public finance.

Correspondence to: Maria-Andrada Georgescu, PhD, University of Political Studies and Public Administration, Faculty of Public Administration, Bdul Expozitiei 30, 010324, Bucuresti, Romania, e-mail: maria-andrada.georgescu@administratiepublica.eu

ORCID (ib) http://orcid.org/0000-0002-4882-7256

\section{Acknowledgements and Financial Disclosure}

The authors would like to thank the anonymous reviewers for their useful comments and feedback that led to improvement in the value of this article.

\section{Copyright and License}

This article is published under the terms of the Creative Commons

Attribution - NoDerivs (CC BY-ND 4.0) License

http://creativecommons.org/licenses/by-nd/4.0/

Published by the Centre for Strategic and International Entrepreneurship - Krakow, Poland 